Volume 7 Issue 1, March 2020

Nationally Accredited Journal,

Decree No. B/4130/E5/E5.2.1/2019

\title{
The Strength Of Evidence Of Deed Made Under Hands Connected With The Authority Of Notary Legalization And Waarmerking Based On Act No. 30 Of 2004 On The Notary Position
}

\author{
Muhammad Dias Saktiawan ${ }^{1}$, Arif Hijrah Saputra² and Ngadino ${ }^{3}$
}

Abstract. This study aims to determine the strength of the deed made under hand as evidence in court, and is there a function legalization and Waarmerking the deed made under hand can provide additional strength of evidence in court. Focused on the research objectives, the formulation of the problem is as follows: First, What is the function of the legalization and Waarmerking deed made under hand in evidence during the trial Court? Second, Do deed made under hand on legalization and in Waarmerking by notaries can be canceled by a judge in court?

The research method used is the method of juridical-normative approach. Specifications in this research is descriptive analytical. The data collection method used in this research is secondary data in the form of primary legal materials that legislation, secondary law namely literature, scientific papers, and tertiary legal materials namely legal materials that support primary legal materials and secondary law. While the methods of data analysis using qualitative data analysis.

The results showed Legalization and Waarmerking function on deed made under the hand give assurance to the judge about the date, signature, identity of the parties to the agreement, thus helping to judge in terms of proof. Deed made under hand on Legalization and in Waarmerking by notary can be canceled by a judge even though the task of the judge in the case only to share the burden of proof to prove, but ex officio judge can not cancel a deed if not requested cancellation. This is because judges are not allowed to decide unsolicited, so as a deed can be canceled if it does not meet the elements of subjective and objective elements.

Keywords: Legalization; Deed; Notary.

\section{Introduction}

Deed is an article that has been deliberately created to be used as evidence of an event and signed by the parties who made it, to the provisions of Article 1867 of the Civil Code an act is divided into 2 (two), namely the authentic act and deed made under hand. ${ }^{4}$

\footnotetext{
${ }^{1}$ Student of Master of Notarial Law, Universitas Islam Sultan Agung and an Advocate, email: diassaktiawan@gmail.com

${ }^{2}$ Student of Master of Law Program, Faculty of Law, Universitas Islam Sultan Agung email ahs lawyers@yahoo.com

${ }_{3}^{3}$ Notary / Land Deed Making Officer (PPAT) at Semarang City

${ }^{4}$ R. Subekti dan R. Rjitrosudibio, 2006, Kitab hukum Undang-Undang Hukum Perdata, Ed-37, Pt.

Pradnya Pramita, Jakarta, p. 39
} 
An authentic deed is a deed made by the competent public authority authentically create or describe something act or a condition seen or witnessed by a public official's deed. A public official in question is a notary, judge, bailiff in a court of law, civil registration clerks, and so on. An authentic act has the strength of evidence was perfect for the parties and all of his heirs or other parties who received the rights of the parties. So that if a party filed an authentic deed, the judge must accept and assume what is written in the deed it really happened, so that the judge may not order additional evidence again. ${ }^{5}$

While the deed made under hand is not on the deed made before the competent authorities or Notary Public. This deed was drawn up and signed by the parties who made it. The deed made under hands of a letter by a signature, which contains the events that form the basis of the right or of the engagement, which was created by deliberate for proof. In Article 138, 165, 167 HIR and Articles 1867 to 1894 of the Civil Code, the deed made under hand is one of the written evidence (letter).If a the deed made under hand is not denied by the parties, it means they recognize and not deny the truth of what is written in the deed made under hand, so that in accordance with article 1857 of the Civil Code the deed made under hand strength of evidence together with an authentic deed, The deed made under hand consists of: ${ }^{6}$

- Deed under ordinary hand

- Deed of Waarmerking, is a deed made under hand and signed by the parties and then registered at the Notary, because only registered, the Notary is not responsible for the material / content and the signatures of the parties in a document made by the parties.

- Legalization of Deed, is a deed made under hand by the parties, but its signing was witnessed by or in the presence of the Notary, but the Notary is not responsible for the material / content of the document but only Notary responsible for the signatures of the parties concerned and the date of signing the document.

In practice, the deed made under hand sometimes used for certain private interests, which sometimes is not the same as when it was created. For example deed made under hand today by date in months and years ago, because there was no obligation to report the deed made under hand, then there is no guarantee that the deed made under hand was made in accordance with the time. Agreements made under the hand is agreement made by the parties and promised, without any fixed rule and simply adapted to the needs of the parties that promise. For proof strength only to the parties if the parties deny or admit the existence of the agreement. According to Subekti, proving is to convince the judge of the truth of the arguments put forward in a dispute $^{7}$, Meanwhile, according to Mertokusumo Sudikno proof is: ${ }^{8}$

"The proof is juridically else is proof historically. This juridical proof are trying to establish what had happened concretely. Both in evidence and scientific juridically,

5 https://notarisarief.wordpress.com/2011/05/15/otentisitas-suatu-akta-otentik/ accessed on October 1, 2018.

${ }^{6} \mathrm{http}: / /$ rahmadvai.blogspot.com/2014/04/pengertian-dan-perbedaan-akta-otentik.html accessed on October 1, 2018

${ }^{7}$ R.Subekti,1998, hukum pembuktian, Djambatan, Jakarta, 2013, p. 133.

${ }^{8}$ Sudikno Mertokusumo, 1999, Hukum Acara Perdata Indonesia, Liberty, Yogyakarta, p.109. 
Volume 7 Issue 1, March 2020

Nationally Accredited Journal,

Decree No. B/4130/E5/E5.2.1/2019

then prove essentially means logically consider why certain events are considered true".

The deed made under hand strength of evidence as evidence in court proceedings connected with the notary authority in the process of legalization and Waarmerking set out in Article 1874 and Article 1874 (a) of the Civil Code requires the legalization of documentary evidence or Waarmerking by authorized officials. This study aims to identify and analyzing the function of legalization and Waarmerking against deed made under hand in evidence during the trial Court and knowing and analyzing whether deed made under hand on legalization and in Waarmerking by notaries can be canceled by a judge in court.

\section{Research Methods}

The method used in this research is normative juridical research is a study of the legal texts alone, but involves the ability of scientific analysis of legal materials to support the understanding of legal theory. While the specification in this research is descriptive analytical.

Data used in the study of normative law is secondary data. Secondary data sources used include the primary legal materials, secondary law and tertiary legal materials. Sources of primary legal materials obtained from the law which has binding force such as the Civil Code, Commercial code, Het Herziene Indonesisch Reglement, S 1941: 44 (HIR), Act No. 4 of 2004 on Judicial Power, Act No. 5 of 2004 On Court Great, and Act No. 30 of 2004 in conjunction with Act No. 2 of 2014 On Notary. While the materials used in the form of secondary law, literature, previous scientific work, and jurisprudence. While the source of tertiary legal materials used in this study are the ingredients that support secondary law and tertiary.

Data collection techniques used in this research is through the research literature. While the analysis of the data used is the data analysis done qualitatively.

\section{Discussion}

\subsection{The Function Of Legalization And Waarmerking Of The Deed Made Under Hand In Evidence In Court Of Justice}

In the civil law of evidence article / letter stated in Section 138.165, $167 \mathrm{HIR}$ / Article 164, 285, 305 and Article Rbg 1867-1894 Civil Code and Articles 138-147 RV. Documentary evidence is the evidence first and foremost, is said to be the first because of the written evidence gradation former compared with the other evidence while saying the main because of the civil law is sought is the formal correctness the documentary evidence was deliberately made to be used as a tool the main evidence, which is evidence or a letter written by Ali Afandi is "something that contains something legible marks and stating a piece of mind". ${ }^{9}$ According to the Positive Law to

\footnotetext{
${ }^{9}$ Anshoruddin. H, 2004, Hukum Pembuktian Menurut Hukum Acara Islam dan Hukum Positif, Pustaka Pelajar, Yogyakarta, p. 69.
} 
prove the events in court is done by using the evidence, the evidence presented that provides a basis to judge the truth of the events postulated, the Law of Civil Procedure has been arranged on the evidence used in the trial judge thus strongly bound by the evidence, so that the judge passed its decisions shall give consideration based on the evidence authorized by law.

Agreements made in writing can be a deed, which generally deed it is a signed letter, containing information about the events or things, which are the basis of an agreement, a deed that can be distinguished in two forms and nature, that is :

- An authentic deed is the deed of a deed made by or in advance of a general staff, by whom in the deed was recorded statement of the parties have a deed that, Officer common question here is the employees are represented by the law has the authority to make the deed authentic. An authentic deed is no denying the truth, unless it can be proved that what the public servants it as true.

- The deed made under hand contains also a record of a legal act, but the difference with the authentic act is that the deed made under hand is not made before the public servants.

According to Prof. Mr. A. Pitlo: "Who is going to make the deed made under hand picked up the pen, who is about to acquire an authentic take on Notary deed". From these expressions can be known who and how to make the deed made under hand and notaries have the authority to make an authentic deed. ${ }^{10}$

The letters below are generally laced hands "know" stamped and signed by the RT, RW, Head of Village, Head of District. The word of knowing that we often encounter with variations among others; "Knowing justify, identify and justify, know and watch, knowing and certify, acknowledge and strengthen, and so forth", the words of the above interesting to be analyzed or discussed, who has the authority for it, and how the legal force as evidence, Interesting to be analyzed or discussed due to such things there is no rule of law, in contrast to Legalization and Waarmerking which has been arranged with stb.1916 46 jo 43 with additions and amendments thereto, prepared in charge, how formulations, and how the legal consequences, so with It is obvious,

In Dutch used the term gezein, means seeing, gezein, en accoor bevonden means seen and approved, the Indonesian generally used the term "know" is not "seen" as the gezein translation. So that "knows" the brevity understand, understand from that that brings, makes the letter was known, understood about the contents of the letter, understands that the letter is really signed by the parties concerned, understand and take responsibility for the accuracy of all who are in the mail it happened, its contents, the signature and the date. Rules on how to mark the papers (deeds) under this hand which regulates how legalizing and Waarmerking letter (certificate) under this deed.

A letter deed made under the hand and has been on Legalization, has the exact date and the certainty of the signature, the certainty of the signature means certain that the signature was indeed the person, not someone else, say so because legalizing the letter hinted should know the person who signature, has the certainty of the date means it is dated at the time, not dated forward or backward, Waarmerking only has certainty dates only and there is no certainty signature.

${ }^{10}$ Kohar A, 1983, Notaris dalam Praktek Hukum, Alumni, Bandung, p.24. 
Volume 7 Issue 1, March 2020

Nationally Accredited Journal,

Decree No. B/4130/E5/E5.2.1/2019

Legalization of the signatures made before legalizing medium for Waarmerking at the time the letter was signed by the person concerned so that gives Waarmerking not know and therefore do not endorse on his signature. In case there is no dispute or no dispute, then the deed made under hand when in Legalization or in Waarmerking no problem, but disputes that may arise at any time, if it appears the dispute as described above which legalized have a secure signature and the certainty of the date while which in Waarmerking only have certainty of the date only. In the case in court all evidence assessed by the judge, including evidence in the form of a letter under the hand especially spiked legalization and Waarmerking,

Based on the above then the deed made under hand that has obtained Legalization or Waarmerking of notaries assist judges in terms of evidence, due to the recognition of such signatures, then the contents of the deed was regarded as the agreement of the parties, because the deed made under hand of truth lies in signatures the parties to the acknowledgment of the signature by the parties and the parties who recognize the signature on the letter means he also recognizes the contents of the letter is on the signature that the certificate is a proof of the perfect.

\subsection{Deed Made Under Hands Which Legalized And In Waarmerking By Notaries Which Can Be Canceled By Judge In Court}

Notary job is to make an authentic deed regarding deeds, agreements and determination desired by the person concerned. Authentic deeds have official proof of perfect strength. This deed is made at the discretion of the parties. So for example facing the people who are still minors ( 15 years) but when facing a notary claimed 22 years old and took account of the ravine was 22 years old. The boy is selling his house, made by a notary deed and then note that the child was actually only 15 years old. It shall remain authentic, what is said in the deed that is true but that legal actions have not been able, so the threat can come at any time of the cancellation of the certificate by the judge if the complaint that should minors who represents the legal act to be her guardian.

Another example, a notary can make the deed when the client known by a notary or introduced to the notary, A sells goods to B, A is not known by the notary because there is no identification, then $A$ is introduced by the witness $B$ and $C$. The Suffice meet legal requirements, two witnesses introduce that he is $A$, the deed was made, but then called $A$ that is not a real, it's someone else, of course this deed can be petitioned to the court to be canceled, the deed of such a defect, the defect is not due to the notary but flawed because the act of the client.

Against the above case can also apply to the certificate under the hands of authorized or recorded by a notary public in the form; Legalization and Waarmerking, if there is a mistake in the making or made not in accordance with the existing regulations on the deed made under hand can be canceled by a judge.

There are several provisions of the law that must be met in performing an act, including the following; 
- Incompetent people should not take legal actions.

- A deed of agreement was made. Terms of agreement that there must be an agreement, the parties must be competent, there should be a particular object, there must be a lawful purpose, otherwise qualify it, then it can be applied for cancellation of the agreement to the court.

- Sale of goods belonging to another person, the seller is not the owner of the goods fail, when facing a notary public that all was not told.

- Buying and selling goods unopened heritage is prohibited though heir permission.

- Approvals are held for reasons kosher, because it means the purpose of the agreement was not contrary to public order, morality, the agreement was not is void.

In essence, that such things the judge assessing whether there is prohibited, there is and whether or not the conditions that must be met in deed. If it exists, then the judge may declare is void (nieting) or irrevocable (vernietingbaar).

Based on the above we may understand, that to the deed made by a public official (Notary Public) in the form of authentic deed or deed made under hand, when made not in accordance with the regulations and legislation in force, against the deed can be canceled or null and is void.

In principle, the task of the judge in the case evidentiary burden to prove just has been, assess whether or not accepted a judge the strength of evidence and proof after proof is held. Judge ex officio in principle can not cancel the good deed authentic act or the deed made under hand if not requested cancellation, because judges are not allowed to decide unsolicited. ${ }^{11}$

Article 178 paragraph (3) HIR stated; "It is forbidden to be passed a decision on the case that no prosecution, or will graduate more than required."

In case of cancellation of the certificate requested by the parties concerned essentially the notarial deed can be canceled by the judge if there is evidence of an opponent, as already mentioned above. If one copy of a notary deed, then copy it is not legally enforceable as written evidence, because the power of the authentic act lies in the original deed (Article 1888 Civil Code). In the event that a notarial deed be a requirement for the validity of a legal act and not be met, such as Articles of Association Limited, the contents and the deed is void (Article 1682, Civil Code 1171), so both actions and the deed is void. A deed which is not legally defective, then the only legal actions are canceled.

Errors in deed, ie, if the shape of a statement of the extraordinary general meeting decisions were supposed meeting minutes, then the deed canceled but it was not. Cancellation raises uncertain circumstances, therefore, the Act gives deadline to sue based on the cancellation. Legislation grants the cancellation when trying to protect a person against himself. The cancellation of a legal act does not mean that legal actions legitimate, valid, if within a certain time limit does not prosecute the cancellation. In the event that there is one party that is not old enough and deemed incompetent can not carry out their interests well, then that party is authorized by law to void the consequences, all the parties concerned are not capable,

${ }^{11}$ Op. Cit., Sudikno Mertokusumo, p.126. 
Volume 7 Issue 1, March 2020

Nationally Accredited Journal,

Decree No. B/4130/E5/E5.2.1/2019

Ratio teachings of this cancellation is that the counterparty is not able to apply for the cancellation to the judge. Based on this it can be seen that the cancellation of the protection of the individual against himself while nullification is the protection of a person against another person.

In case of cancellation of the verdict would indeed necessary, because while not requested cancellation of the agreement or deed it still be valid for the parties to make. While in the case null and is void, if nothing happens then no need nullification dispute was settled by a judge, but if there is a dispute then need nullification was decided by a judge and undoing was retroactive since the agreement was made.

The deed made under hand that has got Legalization or Waarmerking notary can be canceled by a judge even though the task of the judge in the case of proof only share the burden of proving, but ex officio judge can not cancel a deed if not requested cancellation Because judges are not allowed to decide unsolicited. In terms of the deed made under hand that is recognized is requested cancellation, then the judge may cancel the deed if there is evidence of an opponent, a certificate can also be null and is void if the non-fulfillment of a condition of the objective of an agreement and a deed can be canceled by the non-fulfillment of the terms subjective an agreement, but it can also cancellation of the deed made under hand of the notary authority in article 15 paragraph (2) of the Notary Law.

\section{Closing}

\subsection{Conclusion}

- Legalization and Waarmerking function on deed made under hand, that Legalization, provide certainty signature, date and the contents of the deed. Waarmerking, provide certainty regarding the date of registration before the Notary. So the deed made under hand that has obtained Legalization and Waarmerking give assurance to the judge about the date, signature, identity of the parties to the agreement, thus helping the judge in the case of proof as to the recognition of the signature and date of the deed.

- Ex officio judge can not cancel a deed if not requested cancellation. This is because judges are not allowed to decide unsolicited, such a deed can be canceled if it does not meet the elements of subjective and objective elements of an agreement and / or do not meet the requirements and procedures for it according to the Notary Act. In terms of the deed made under hand, then the judge may cancel the certificate if requested and there is evidence of an opponent.

\subsection{Suggestion}

- Legalization and Waarmerking manufacture, it is expected that the Notary can seriously pay attention to all the provisions of the relevant legislation to void legal problems later on. 


\section{JURNAL AKTA}

eISSN : 2581-2114, pISSN: 2406-9426

- The parties are facing a notary should always help the notary to express the real thing based on good faith and honesty, so that the deed was perfect and in accordance with applicable law.

\section{Bibliography}

[1] Anshoruddin. H, 2004, Hukum Pembuktian Menurut Hukum Acara Islam dan Hukum Positif, Pustaka Pelajar, Yogyakarta.

[2] Kohar A, 1983, Notaris dalam Praktek Hukum, Alumni, Bandung.

[3] R.Subekti,1998, Hukum Pembuktian, Djambatan, Jakarta.

[4] R. Subekti dan R. Rjitrosudibio, 2006, Kitab hukum Undang-Undang Hukum Perdata, Cet. Ke-37, Pt. Pradnya Pramita, Jakarta,

[5] Sudikno Mertokusumo, 1999, Hukum Acara Perdata Indonesia, Liberty, Yogyakarta.

[6] https://notarisarief.wordpress.com/2011/05/15/otentisitas-suatu-akta-otentik/

[7] http://rahmadvai.blogspot.com/2014/04/pengertian-dan-perbedaan-akta-otentik. 